\title{
INHIBITORY EFFECTS OF PROCAINE ON THE ELECTRICAL AND MECHANICAL ACTIVITIES OF THE SMOOTH MUSCLE CELLS OF THE GUINEA PIG URINARY BLADDER
}

\author{
Satoshi Kurihara and Toshio SAKaI \\ Department of Physiology, The Jikei University School of Medicine, \\ 3-25-8, Nishishinbashi, Minato-ku, Tokyo 105, Japan
}

\begin{abstract}
Modification of the effects of $\mathrm{K}, \mathrm{Ca}$, acetylcholine and rapid cooling by procaine were examined in the smooth muscle of the guinea pig urinary bladder. Contraction enhancement by procaine was observed in $5.9 \mathrm{~mm} \mathrm{~K}$ - and $23.6 \mathrm{~mm} \mathrm{~K}$-Krebs solutions but was not confirmed in $59 \mathrm{~mm} \mathrm{~K}$ solution. Procaine enhanced contraction in relation to membrane activities. Relationships between membrane potential and $\mathrm{K}$ concentration showed that procaine reduced $\mathrm{K}$ conductance. This effect decreased as $\mathrm{K}$ concentration increased. $\mathrm{K}$-induced contracture was inhibited by procaine at $37^{\circ}$ and $10^{\circ} \mathrm{C}$. Procaine inhibited $\mathrm{Ca}-$ and acetylcholine-induced contractions in isotonic $\mathrm{K}_{2} \mathrm{SO}_{4}$-Locke solution. Rapid cooling contracture, initiated by lowering the temperature of the solution from $36 \pm 1^{\circ} \mathrm{C}$ to $12 \pm 2^{\circ} \mathrm{C}$ within $30 \mathrm{sec}$, was inhibited by procaine.

From these results, it is concluded that procaine has an inhibitory effect on $\mathrm{Ca}$ permeation through the cell membrane and on $\mathrm{Ca}$ release from sequestered sites, and it is confirmed that procaine enhancement of spontaneous contractions is related to the spike activity resulting from depolarization which is caused by reduction of $\mathrm{K}$ conductance (KURIHARA, 1975). The mechanism of the procaine effect is discussed in relation to excitation-contraction coupling in the guinea pig urinary bladder.
\end{abstract}

It has been reported that procaine enhances spontaneous rhythmic contractions in the smooth muscles of the bullfrog and guinea pig urinary bladder, and that it especially reduces $\mathrm{K}$ conductance and causes depolarization in the guinea pig urinary bladder and taenia coli (BÜLBRING and KURIYAMA, 1973; KURIHARA, 1973, 1975; KurIHARA and SAKAI, 1976). In the smooth muscle of the guinea pig urinary bladder, it is suggested that procaine stimulation of spontaneous contractions is closely related to the Ca spikes which play an important role in excita-

Received for publication June 29, 1976

栗原 敏, 酒井敏夫 
tion-contraction coupling.

On the other hand, Feinstein (1966) and Feinstein and PAimre (1969) reported that procaine showed nonspecific inhibition of smooth muscle contraction, a result attributed to the inhibition of $\mathrm{Ca}$ permeation through the cell membrane and through the intracellular membrane system of the smooth muscle.

In the present experiments, the effects of procaine on $\mathrm{Ca}$ permeation through the cell membrane and $\mathrm{Ca}$ release from sequestered sites of the smooth muscle of the guinea pig urinary bladder were investigated under the various conditions.

Some of the results were presented at the 17th Annual Meeting of Japanese Smooth Muscle Society in 1975.

\section{METHODS AND MATERIALS}

Guinea pigs of either sex weighing 250-300 g were used in the present experiment. The method of preparing the smooth muscle of the bladder was similar to that described by CREED (1971).

A modified Krebs solution with the following composition was used (mM): $\mathrm{Na}^{+}, 137.4 ; \mathrm{K}^{+}, 5.9 ; \mathrm{Mg}^{++}, 1.2 ; \mathrm{Ca}^{++}, 2.5 ; \mathrm{Cl}^{-}, 134.0 ; \mathrm{HCO}_{3}^{-}, 15.5 ; \mathrm{H}_{2} \mathrm{PO}_{4}^{-}$, 1.2 , and glucose 11.5 ; the solution was equilibrated with $97 \% \mathrm{O}_{2}$ and $3 \% \mathrm{CO}_{2}$. Krebs solutions having various $\mathrm{K}$ concentrations were prepared by isotonic replacement of $\mathrm{NaCl}$ with $\mathrm{KCl}$ and $\mathrm{NaHCO}_{3}$ with $\mathrm{KHCO}_{3}$. In some experiments, a Locke solution with the following composition was employed (mM): $\mathrm{Na}^{+}$, $154.0 ; \mathrm{K}^{+}, 5.6 ; \mathrm{Ca}^{++}, 2.2 ; \mathrm{Cl}^{-}, 164 ;$ glucose 5.5 and Tris (hydroxymethyl aminomethane)-maleate buffer, 5 ; the solution was equilibrated with $100 \% \mathrm{O}_{2}$. For preparing $\mathrm{K}_{2} \mathrm{SO}_{4}$-Locke solution, $154 \mathrm{mM} \mathrm{NaCl}$ in Locke solution was replaced with $126 \mathrm{mM} \mathrm{K}_{2} \mathrm{SO}_{4}$ (Evans et al., 1958). The $\mathrm{pH}$ of all solutions was 7.2-7.4 as measured with a Hitachi-Horiba $\mathrm{pH}$ meter, type F-7DE. Procaine- $\mathrm{HCl}$ and acetylcholine chloride were products of E. Merck and Daiichi Pharmacy Co., Ltd., respectively.

The solution was passed via polyethylene tube through a warm water bath the temperature of which was kept at $38^{\circ}-39^{\circ} \mathrm{C}$ by Thermo Unit (type C-550, Taiyo Co., Ltd.) and the tissue preparation was irrigated with the solution at $36 \pm 1{ }^{\circ} \mathrm{C}$ continuously. When the temperature of the solution was lowered, the solution was passed through a cooled water bath at a temperature of either $29^{\circ}$ or $10^{\circ} \mathrm{C}$ by a Coolnics Circulator (model CTE-120, Yamato Scientific Instruments Co., Ltd.). In rapid cooling experiments, the temperature of the solution was lowered from $36 \pm 1{ }^{\circ} \mathrm{C}$ to $12 \pm 2^{\circ} \mathrm{C}$ within $30-40 \mathrm{sec}$.

To observe muscle tension and spike activity simultaneously, the single sucrose gap method similar to that described by KURIHARA (1975) was employed. Muscle isometric tension and spike activity were recorded with a pen-writing oscillograph (RM-25, Nihon Kohden Co., Ltd.). The mechano-transducer was a strain gauge (SB-1T, Nihon Kohden Co., Ltd.).

The membrane potential of the smooth muscle cells was recorded with con- 
ventional glass capillary microelectrodes filled with $3 \mathrm{M} \mathrm{KCl}$. The maximum rates of rise and fall of the spike were measured through a differential operational amplifier. Measured values were represented as mean $\pm S$. D.

\section{RESULTS}

Effect of procaine in Krebs solutions having various $K$ concentrations

Procaine enhanced spontaneous rhythmic contractions by increasing spike discharges in normal Krebs solution and in a $23.6 \mathrm{~mm} \mathrm{~K}-\mathrm{Krebs}$ solution. In the $59 \mathrm{~mm}$ K-Krebs solution, however, procaine did not enhance, but rather inhibited the $\mathrm{K}$-induced contraction without spike activity changes (Fig. 1). In order to observe the relation between the $\mathrm{K}$ ion concentration and the procaine effect in various concentrations of $\mathrm{K}$ ion, membrane potentials and mechanical responses were recorded simultaneously using a microelectrode and a strain gauge, respectively. Figure 2 shows a simultaneous record of the effect of procaine on the mechanical and electrical activities in a high $\mathrm{K}-\mathrm{Krebs}$ solution. After increasing the $\mathrm{K}$ ion concentration in the Krebs solution from 5.9 to $23.6 \mathrm{mM}, 15 \mathrm{~mm}$ procaine was added to $23.6 \mathrm{~mm} \mathrm{K-Krebs} \mathrm{solution.} \mathrm{Procaine} \mathrm{increased} \mathrm{the} \mathrm{spike} \mathrm{amplitude} \mathrm{and}$

a)

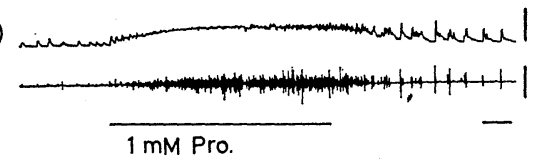

b)
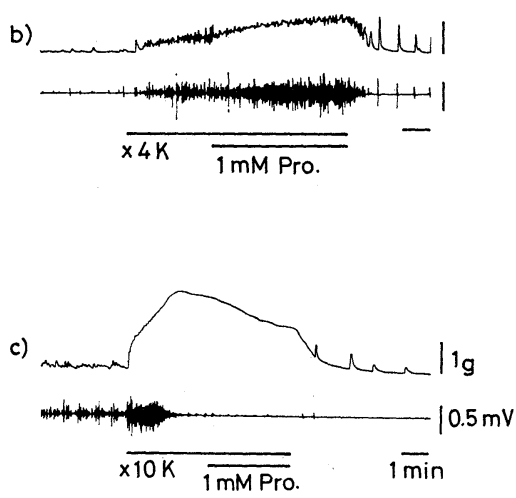

Fig. 1. Effects of procaine on mechanical response in Krebs solutions having various $\mathrm{K}$ concentrations. Upper trace: tension. Lower trace: spike activity recorded using single sucrose gap method. (a): $1 \mathrm{~mm}$ procaine was applied to normal Krebs solution for $8 \mathrm{~min}$. (b): $3 \mathrm{~min}$ after immersion in $23.6 \mathrm{~mm}$ K-Krebs solution, $1 \mathrm{~mm}$ procaine was added for $5 \mathrm{~min}$. (c): $3 \mathrm{~min}$ after immersing in $59 \mathrm{~mm}$ K-Krebs solution, $1 \mathrm{~mm}$ procaine was applied for $3 \mathrm{~min}$. 
a)
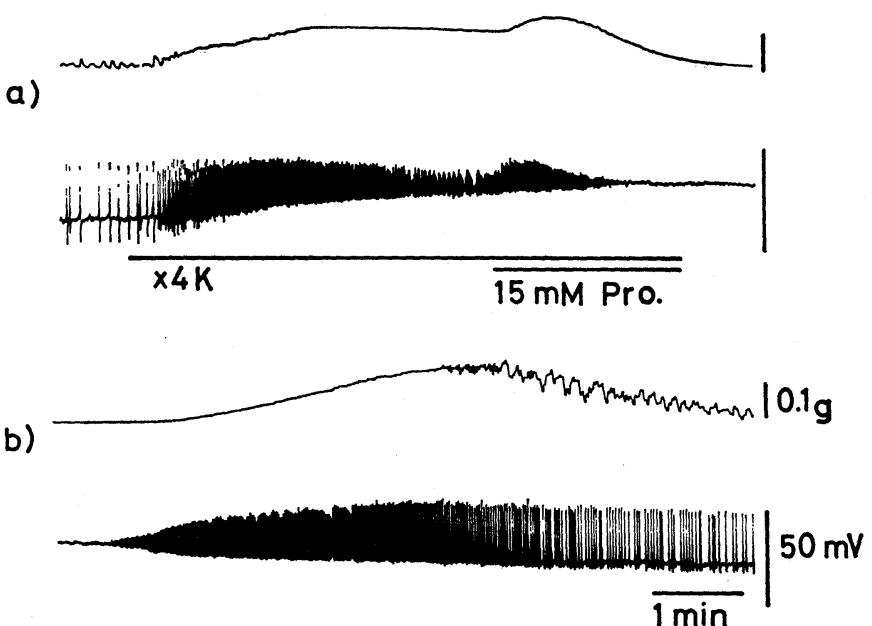

Fig. 2. Effects of $15 \mathrm{~mm}$ procaine on mechanical response and membrane potential in 23.6 mM K-Krebs solution. Upper trace: tension. Lower trace: membrane potential recorded using a microelectrode. (a): 4 min after immersing preparation in $23.6 \mathrm{~mm}$ K-Krebs solution, $15 \mathrm{~mm}$ procaine was added for $2 \mathrm{~min}$. (b): Preparation was then rinsed with normal Krebs solution. After rinsing with normal Krebs solution, spike activity and tension recovered.

mechanical response transiently. When the depolarization reached its steady level and spike activity ceased, tension decreased to the control level which was observed in normal Krebs solution. On washing out the preparation with normal Krebs solution without procaine, the membrane was repolarized, and spike activity and tension recovered.

Figure 3 is a graph of membrane potentials measured in Krebs solutions containing various concentrations of $\mathrm{K}$ ion in the presence or absence of $15 \mathrm{~mm}$ procaine. The equilibrium potential of $\mathrm{K}$ ion $\left(E_{\mathrm{K}}\right)$ in Fig. 3 was calculated from the value obtained for guinea pig taenia coli (CASTEELS, 1970). It is reported that the membrane potential in taenia coli can not be explained by the simple Nernst equation (CASTEELS and KURIYAMA, 1966). The relationships between membrane potential and $\mathrm{K}$ concentration in the absence of procaine did not obey the simple Nernst equation for $\mathrm{K}$ ion and was also different from that obtained for taenia coli as discussed by KURIHARA and CREED (1972). In the presence of $15 \mathrm{~mm}$ procaine, membrane potential deviated still further from the control. But in Krebs solutions with a high $\mathrm{K}$ concentration, the effect, though still observed, was very small.

Figure 4 shows effects of procaine (1 and $3 \mathrm{~mm}$ ) on K-induced contracture. After observing $\mathrm{K}$-contracture, using isotonic $\mathrm{KCl}$ as a control (Fig. 4a), the preparation was bathed in normal Krebs solution for $30 \mathrm{~min}$. Procaine (1 mM) was then added to the solution. Four minutes later, isotonic K-Krebs solution was also added for $3 \mathrm{~min}$ (Fig. $4 \mathrm{~b}$ ). The same procedure was repeated using $3 \mathrm{~mm}$ procaine (Fig. 4c). Phasic and tonic responses of $\mathrm{K}$-induced contracture were markedly 


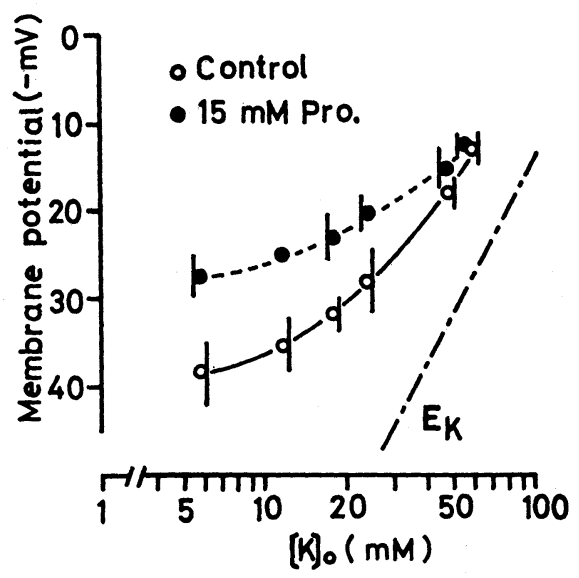

Fig. 3. Relationships between $\mathrm{K}$ ion concentration and membrane potential in presence and absence of $15 \mathrm{~mm}$ procaine. Membrane potential without procaine was measured 5 to $10 \mathrm{~min}$ after changing $\mathrm{K}$ ion concentration. Membrane potential with procaine was obtained 5 to $8 \mathrm{~min}$ after addition of procaine. $E_{\mathrm{K}}$ : equilibrium potential of $\mathrm{K}$ ion calculated from data obtained for taenia coli of guinea pig. Open circles: membrane potentials without procaine. Closed circles: with $15 \mathrm{~mm}$ procaine. Vertical bars: $\pm \mathrm{S}$. D.

a)

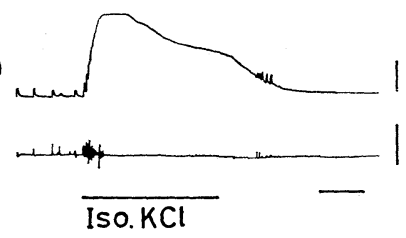

b)
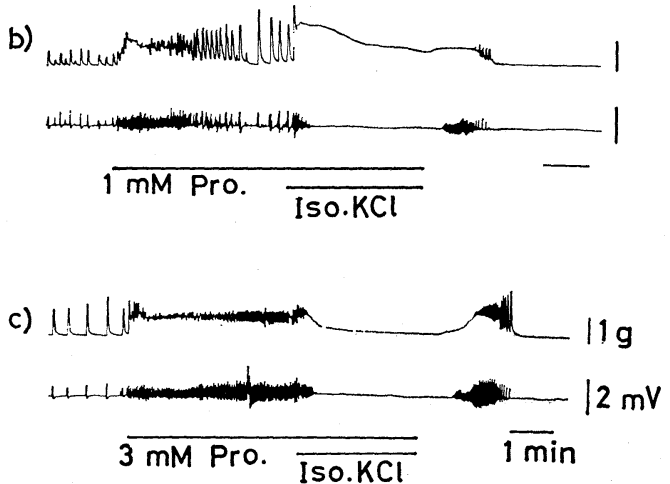

Fig. 4. Effect of procaine on K-induced contracture. (a): Isotonic K-Krebs solution was applied for $3 \mathrm{~min}$ as control. (b): $4 \mathrm{~min}$ after addition of $1 \mathrm{~mm}$ procaine, isotonic K-Krebs solution was applied. (c): Same procedure as (b), but using $3 \mathrm{~mm}$ procaine. Upper trace: tension. Lower trace: spike activity using sucrose gap method. 
inhibited by pretreatment with procaine.

Effect of procaine (1 and $10 \mathrm{~mm}$ ) on the tonic response of $\mathrm{K}$-induced contracture was observed at $37^{\circ}$ and $10^{\circ} \mathrm{C}$ (Fig. 5). After immersing the preparation in isotonic $\mathrm{K}-\mathrm{Krebs}$ solution at $37^{\circ} \mathrm{C}$ for $15 \mathrm{~min}$, procaine $(1 \mathrm{mM})$ was applied for $10 \mathrm{~min}$ (Fig. 5a). The preparation was then rinsed for $20 \mathrm{~min}$ with normal Krebs solution. After 20 min the temperature of the normal Krebs solution was lowered to $10^{\circ} \mathrm{C}$, and after $5 \mathrm{~min}$ isotonic $\mathrm{K}-\mathrm{Krebs}$ solution at $10^{\circ} \mathrm{C}$ was applied. Procaine $(1 \mathrm{mM})$ was then also applied for $10 \mathrm{~min}$ (Fig. $5 \mathrm{~b}$ ). The same procedure was repeated using $10 \mathrm{~mm}$ procaine. Procaine $(1$ and $10 \mathrm{~mm})$ suppressed the tonic response of $\mathrm{K}$-induced contracture with the inhibitory effect of $10 \mathrm{~mm}$ procaine being stronger than that of the $1 \mathrm{~mm}$ procaine. The rate of relaxation of tonic response induced by procaine at $10^{\circ} \mathrm{C}$ was slower than the rate at $37^{\circ} \mathrm{C}$. This effect is clearly shown in each record in Fig. 5 by the change of slope which appears directly above the beginning of the procaine application.

Effect of procaine on Ca-and acetylcholine-induced contractions in depolarized muscle

The application of $\mathrm{Ca}$ to depolarized smooth muscle induces contraction and cell membranes are very permeable to Ca (EDMAN and SCHILD, 1962; URAKAWA and Holland, 1964; ImAI and TAKEDA, 1967). Effect of procaine on Ca-induced contraction was examined in an isotonic $\mathrm{K}_{2} \mathrm{SO}_{4}$-Locke solution (Fig. 6). During immersion of the preparation in $\mathrm{K}_{2} \mathrm{SO}_{4}$-Locke solution without $\mathrm{Ca}$ for $35 \mathrm{~min}$, the preparation was stabilized by adding and removing $0.28 \mathrm{mM} \mathrm{Ca}$ two or three times. The concentration of $\mathrm{Ca}$ was then increased from $0.28 \mathrm{mM}$ to $2.2 \mathrm{~mm}$ in increments as shown in Fig. 6 b. Ten minutes after removal of the $2.2 \mathrm{~mm} \mathrm{Ca}$ from the solution, $0.5 \mathrm{~mm}$ procaine was applied. Five minutes after application of $0.5 \mathrm{~mm}$ procaine, Ca was again added to the solution as in (b) (Fig. 6c). Procaine inhibited

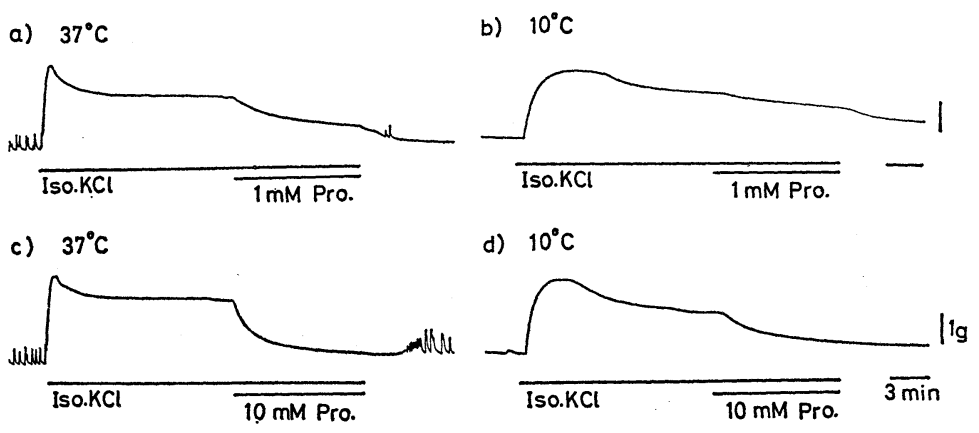

Fig. 5. Effect of procaine $(1$ and $10 \mathrm{~mm})$ on $\mathrm{K}$-induced contracture at $37^{\circ}$ and $10^{\circ} \mathrm{C}$. (a): After isotonic K-Krebs solution at $37^{\circ} \mathrm{C}$ was applied for $15 \mathrm{~min}, 1 \mathrm{~mm}$ procaine was added for $10 \mathrm{~min}$. (b): For $20 \mathrm{~min}$, preparation was immersed in normal Krebs solution, and then temperature of Krebs solution was lowered to $10^{\circ} \mathrm{C}$. Five min later, isotonic $\mathrm{K}-\mathrm{Krebs}$ solution at $10^{\circ} \mathrm{C}$ was applied for $15 \mathrm{~min}$, followed by application of $1 \mathrm{~mm}$ procaine for $10 \mathrm{~min}$. (c) and (d): Same as (a) and (b) but using $10 \mathrm{~mm}$ procaine. 
a)

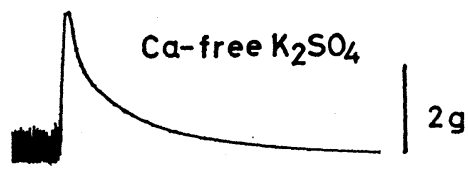

b)

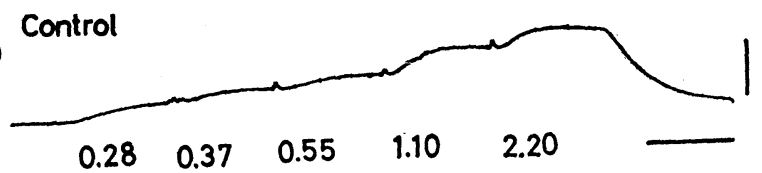

c) $0.5 \mathrm{mM}$ Pro.

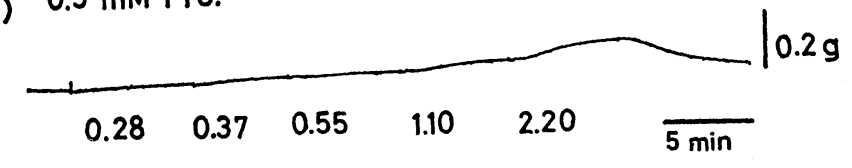

Fig. 6. Effect of procaine on Ca-induced contraction in depolarized muscle. (a): Preparation bathed in Locke solution was rinsed with isotonic $\mathrm{K}_{2} \mathrm{SO}_{4}$-Locke (Ca-free) solution for $35 \mathrm{~min}$. During $35 \mathrm{~min}, 0.28 \mathrm{~mm}$ Ca was applied 2 or 3 times every $5 \mathrm{~min}$ to stabilize tension (not shown). (b): Concentration of $\mathrm{Ca}(0.28,0.37,0.55,1.10$, and $2.20 \mathrm{~mm}$ ) was increased stepwise. (c): $10 \mathrm{~min}$ after elimination of $2.2 \mathrm{mM} \mathrm{Ca}, 0.5 \mathrm{~mm}$ procaine was applied for $5 \mathrm{~min}$, and same procedure as (b) repeated. When high concentrations of $\mathrm{Ca}$ are used, risk of excessive product $[\mathrm{Ca}]\left[\mathrm{SO}_{4}\right]$ should be considered. Ca concentration used in present experiment did not exceed $2.2 \mathrm{~mm}$.

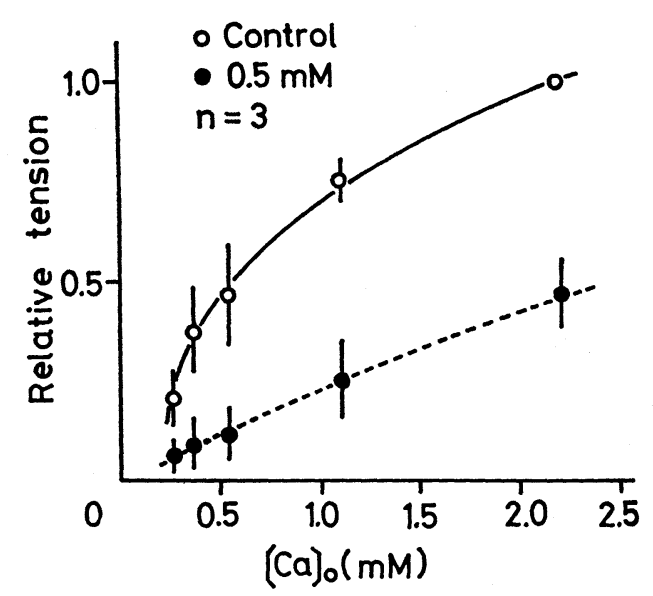

Fig. 7. Relationships between $\mathrm{Ca}$ concentration and relative tension of $\mathrm{Ca}$-induced contraction in isotonic $\mathrm{K}_{2} \mathrm{SO}_{4}$-Locke solution in presence or absence of $0.5 \mathrm{~mm}$ procaine. Data obtained from 3 preparations. Open circles: without procaine. Closed circles: with $0.5 \mathrm{~mm}$ procaine. Vertical bars: \pm S. D. 
the Ca-induced contraction in isotonic $\mathrm{K}_{2} \mathrm{SO}_{4}$-Locke solution. Relations between $\mathrm{Ca}$ concentration and the relative tension of $\mathrm{Ca}$-induced contraction with and without procaine, are represented in Fig. 7. Relative tension induced by various concentrations of $\mathrm{Ca}$ were calculated from 3 preparations, with peak tension induced by $2.2 \mathrm{~mm}$ Ca without procaine taken as unity. In the presence of procaine, $\mathrm{Ca}$ induced contraction was markedly inhibited. The mechanism may be one in which procaine competes for $\mathrm{Ca}$ permeation through the cell membrane, a possibility which was confirmed by double reciprocal plots.

According to Evans et al. (1958) acetylcholine induces contraction in smooth muscle which has been depolarized by isotonic $\mathrm{K}_{2} \mathrm{SO}_{4}$ solution. The effect of procaine on this acetylcholine-induced contraction was examined (Fig. 8). After immersing the preparation in $\mathrm{K}_{2} \mathrm{SO}_{4}$-Locke solution for $20 \mathrm{~min}$ (Fig. 8a), acetylcholine $\left(10^{-5} \mathrm{M}\right)$ was applied for $2 \mathrm{~min}$ every $5 \mathrm{~min}$ (Fig. $8 \mathrm{~b}$ ). Both the resting tension and the acetylcholine-induced contraction peaks gradually decreased until the resting tension showed a steady level. After addition of $0.5 \mathrm{~mm}$ procaine for $2.5 \mathrm{~min}$, the acetylcholine-induced contraction was inhibited. On removing procaine from the solution, the acetylcholine-induced contraction was partially recovered.

\section{Effect of procaine on rapid cooling contracture}

According to SAKAI (1963), in skeletal muscle fibres treated with low concentration of caffeine, contracture is observed when the temperature of the bathing solution is lowered rapidly from room temperature to about $0^{\circ} \mathrm{C}$ (rapid cooling contracture). Rapid cooling contracture in skeletal muscle fibres is considered to be induced by released $\mathrm{Ca}$ ion especially from the sarcoplasmic reticulum (SAKAI $e t$ al., 1971).

In the taenia coli and urinary bladder of the guinea pig, rapid cooling contrac-
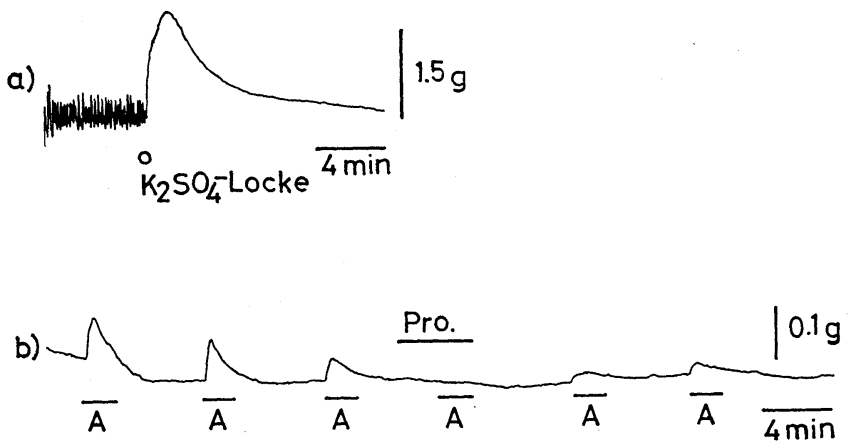

Fig. 8. Effect of procaine $(0.5 \mathrm{~mm})$ on acetylcholine-induced contraction in isotonic $\mathrm{K}_{2} \mathrm{SO}_{4}$ Locke solution. (a): $\mathrm{K}_{2} \mathrm{SO}_{4}$-Locke solution was applied to preparation. (b): Twenty min later, acetylcholine $\left(10^{-5} \mathrm{M}\right)$ was applied 3 times every $5 \mathrm{~min}$ (shown as A). $2.5 \mathrm{~min}$ after addition of $0.5 \mathrm{~mm}$ procaine (Pro.), acetylcholine did not produce tension. After removing procaine, acetylcholine-induced contraction partially recovered. 
ture is observed when the temperature of normal or isotonic K-Krebs solutions without caffeine is rapidly lowered from $36^{\circ} \mathrm{C}$ to about $10^{\circ} \mathrm{C}$. This $\mathrm{RCC}$ is also considered to be initiated by mobilization of sequestered Ca (KURIHARA et al., 1974; MAGARIBUCHI et al., 1973). Using a rapid cooling technique, the effect of procaine on the mobilization of sequestered $\mathrm{Ca}$ was examined.

Before the experiment on rapid cooling contracture, the effect of moderate low temperature (about $30^{\circ} \mathrm{C}$ ) on procaine action in Krebs solution was examined (Figs. 9 and 10). On the application of $1 \mathrm{~mm}$ procaine, resting tension, rhythmic contractions, and spike discharges increased. When the temperature of the solution was gradually lowered from $36^{\circ} \mathrm{C}$ to $30^{\circ} \mathrm{C}$, all three of these increased values diminished. Restoration of the temperature to $36^{\circ} \mathrm{C}$ increased rhythmic contractions; tension and spike discharges reappeared (Fig. 9a). On the addition of $15 \mathrm{~mm}$ procaine, resting tension increased transiently accompanying spike discharges and then gradually decreased (Fig. 9b). Lowering the temperature from $36^{\circ} \mathrm{C}$ to $29^{\circ} \mathrm{C}$ again increased resting tension. After long exposure to $15 \mathrm{~mm}$ procaine at $37^{\circ} \mathrm{C}$, spike discharges partially or completely disappeared and resting tension decreased. On lowering the temperature, however, spike discharges reappeared and resting tension increased again (the third trial in Fig. 9b). To clarify the effect of low temperature in $15 \mathrm{~mm}$ procaine, membrane potential changes at low temperature were observed using a glass microelectrode (Fig. 10). After confirming the membrane potential oscillation induced by $15 \mathrm{~mm}$ procaine (Fig. 10b, left), temperature of the solution was gradually lowered from $34^{\circ} \mathrm{C}$ to $28^{\circ} \mathrm{C}$. The membrane repolarized and large action potentials at a decreased rate were observed (Fig. 10b, right). The after-hyperpolarization of the spike of the control, which was abolished by the procaine, also reappeared at low temperature. On restoring the temperature, the membrane again depolarized and membrane oscillations were observed (Fig. 10c). However, the membrane is depolarized in normal Krebs solution at low
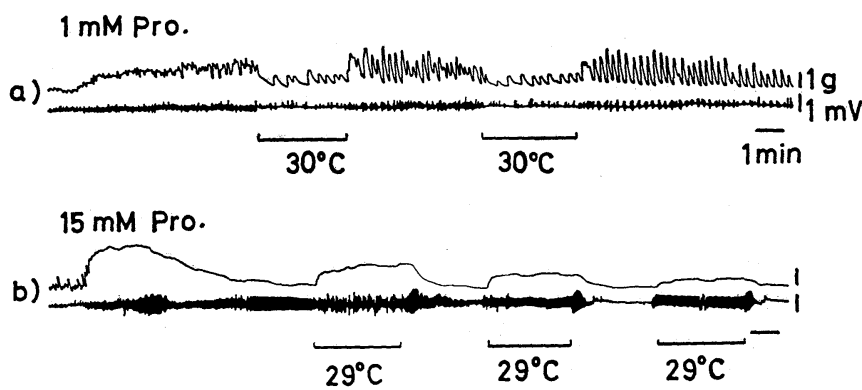

Fig. 9. Effect of low temperature (approximately $29^{\circ} \mathrm{C}$ ) on procaine action (1 and $15 \mathrm{~mm}$ ). (a): After confirming $1 \mathrm{~mm}$ procaine effect, temperature of Krebs solution with procaine was lowered from $37^{\circ} \mathrm{C}$ to $30^{\circ} \mathrm{C} 2$ times every $4.5 \mathrm{~min}$. Note decrease in tension and spike activity. (b): After confirming $15 \mathrm{~mm}$ procaine effect, temperature of solution was lowered from $37^{\circ} \mathrm{C}$ to $29^{\circ} \mathrm{C} 3$ times every $3 \mathrm{~min}$. Note increase in tension and spike activity. Upper trace: tension. Lower trace: spike activity using sucrose gap method. 

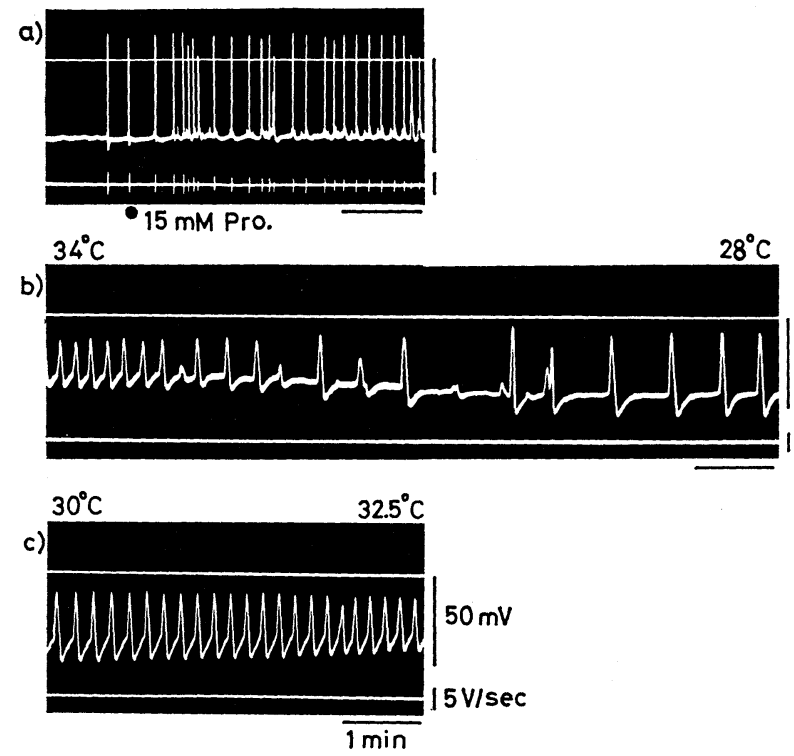

Fig. 10. Effect of low temperature on membrane potential in presence of $15 \mathrm{~mm}$ procaine. Upper line: $0 \mathrm{mV}$. Middle trace: membrane potential recorded using glass microelectrode. Lower trace: maximum rates of rise and fall of spike. (a): $15 \mathrm{~mm}$ procaine was added at closed circle. (b): $15 \mathrm{~min}$ after addition of procaine, temperature of solution was lowered from $34^{\circ} \mathrm{C}$ to $28^{\circ} \mathrm{C}$ gradually. Note repolarization, large spike amplitude, and reappearance of spike after-hyperpolarization. (c): Rewarming to $32.5^{\circ} \mathrm{C}$ gradually. Note gradual depolarization and reduction of spike amplitude.

temperature (KURIHARA et al., 1974). From these results, it was considered that lowering the temperature of the Krebs solution containing procaine might suppress the procaine effect and that it would be difficult to observe the effect of procaine on rapid cooling contracture in normal Krebs solution.

In order to eliminate membrane potential change induced by lowering the temperature, effect of procaine on rapid cooling contracture was examined using preparation depolarized in isotonic K-Krebs solution. Figure 11 shows the effect of $10 \mathrm{~mm}$ procaine on rapid cooling contracture in isotonic K-Krebs solution. Thirty minutes after immersing the preparation in isotonic $\mathrm{K}-\mathrm{Krebs}$ solution, the temperature of the solution was lowered from $36 \pm 1{ }^{\circ} \mathrm{C}$ to $12 \pm 2^{\circ} \mathrm{C}$ for 1.5 min every 10 min. Procaine inhibited rapid cooling contracture (Fig. 11e, f), but its effect was reversible (Fig. 11g, h, i). At low procaine concentration, the peak tension of rapid cooling contracture did not decrease so much, but contracture could not be sustained during cooling. Rapid cooling contracture tension relative to peak tension of $\mathrm{K}$-induced contracture (taken as unity) was plotted as a function of time (Fig. 12). Procaine inhibited rapid cooling contracture and its inhibitory effect was stronger at a higher concentration. 

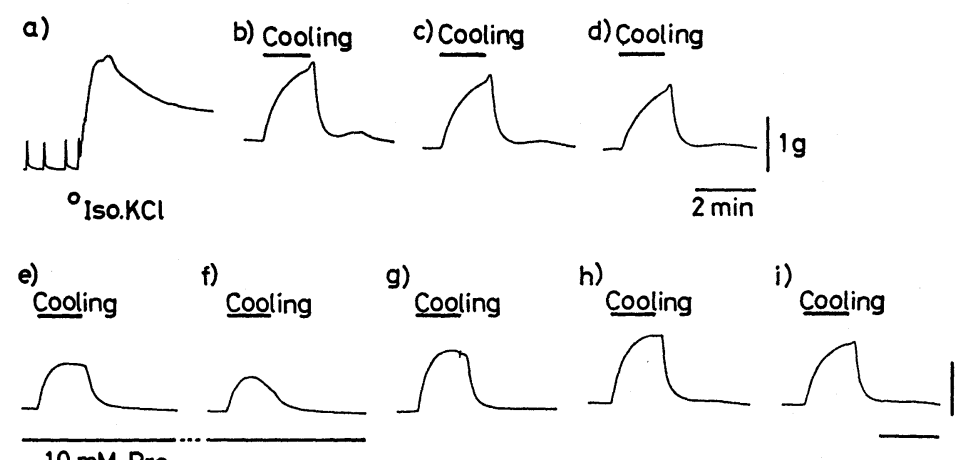

Fig. 11. Effect of procaine $(10 \mathrm{~mm})$ on rapid cooling contracture. Thirty min after immersion in isotonic K-Krebs solution, temperature of solution was lowered from $37^{\circ} \mathrm{C}$ to $12^{\circ} \mathrm{C}$ for $1.5 \mathrm{~min}$ every $10 \mathrm{~min}(\mathrm{a}, \mathrm{b}, \mathrm{c}, \mathrm{d})$. Six min after application of $10 \mathrm{~mm}$ procaine, rapid cooling contracture was slightly inhibited (e), and was further inhibited after $10 \mathrm{~min}$ (f). After removing procaine, rapid cooling contracture recovered $(\mathrm{g}, \mathrm{h}, \mathrm{i})$.

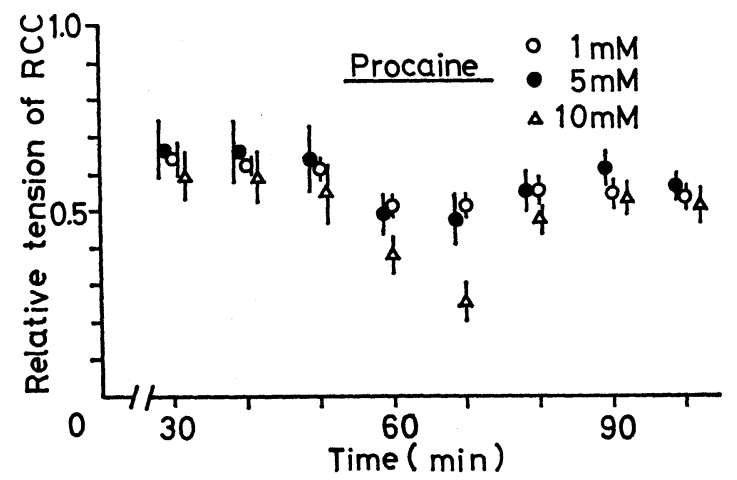

Fig. 12. Effects of procaine (1, 5, and $10 \mathrm{~mm})$ on rapid cooling contracture. Peak tension of $\mathrm{K}$ contracture was taken as unity. Thirty min after immersion in isotonic K-Krebs solution, rapid cooling contracture was observed every $10 \mathrm{~min}$. Application of procaine shown as black bar. Open circles: $1 \mathrm{~mm}$. Closed circles: $5 \mathrm{~mm}$. Open triangles: $10 \mathrm{~mm}$. Data obtained from 3 preparations and represented as mean $\pm \mathbf{S}$. D.

\section{DISCUSSION}

In previous reports (Kurihara, 1975; Kurihara and SAKaI, 1976), it was suggested that procaine reduced $\mathrm{K}$ conductance in the guinea pig urinary bladder smooth muscle. The effect of procaine on the relationships between $\mathrm{K}$ concentration and membrane potential in the present experiment further supports this conclusion. Furthermore, procaine does not enhance contractions in high K-Krebs solutions, and enhancement of contraction by procaine is dependent on membrane depolarization and spike amplitude. This result further confirms the hypothesis that enhancement of contractions by procaine may be due to increase of Ca spikes 
which are initiated by the reduction of $\mathrm{K}$ conductance.

After avoiding the procaine effects on membrane potential and spike activity by immersing the preparation in isotonic K-Krebs solution, procaine inhibits the tonic response of $\mathrm{K}$-induced contracture at $37^{\circ} \mathrm{C}$ and $10^{\circ} \mathrm{C}$. Since the rate of relaxation of the tonic response induced by procaine, in isotonic $\mathrm{K}-\mathrm{Krebs}$ solution, at $10^{\circ} \mathrm{C}$ is slower than that at $37^{\circ} \mathrm{C}$, and since the procaine effect in normal Krebs solution also varies with temperature, procaine effects are obviously dependent on temperature (Figs. 5, 9, and 10). Procaine also markedly inhibits phasic response of $\mathrm{K}$-induced contracture (Fig. 4). The sources of $\mathrm{Ca}$ which produces the phasic and tonic responses of $\mathrm{K}$-induced contracture in smooth muscle are not yet fully understood. Just as tonic and phasic responses of the $\mathrm{K}$-induced contracture in the taenia coli are considered to be dependent on $\mathrm{Ca}$ influx through the cell membrane and Ca mobilization from sequestered sites (URAKAWA and HoLLAND, 1964; IMAI and TAKEDA, 1967), procaine effects on the urinary bladder are also considered to inhibit $\mathrm{Ca}$ permeation and mobilization.

These considerations mentioned above, were further confirmed by the experiments on Ca- and acetylcholine-induced contractions in depolarized preparations. FeinsteIn and PAIMre (1969) reported that Ca- and acetylcholine-induced contractions were inhibited by procaine and that the procaine effect was attributable to the inhibition of $\mathrm{Ca}$ permeation through the cell membrane and the intracellular membrane system. The present experimental results on $\mathrm{Ca}$ - and acetylcholine-induced contractions agree with the above-mentioned results.

On the other hand, it is reported that $\mathrm{Ca}$ release from its stored sites, induced by rapid cooling in skeletal and smooth muscles treated with caffeine, is inhibited by procaine (SAKAI, 1963; SAKAI and IIZUKA, 1972). The inhibitory effect of procaine on Ca release from sarcoplasmic reticulum of skeletal muscle is confirmed by WEBER and HERz (1968).

Recently, however, it has been demonstrated that the charged form of procaine acts as an inhibitor of $\mathrm{Ca}$ release from the sarcoplasmic reticulum while the uncharged form exerts a Ca releasing effect (BIANCHI and Bolton, 1967; FeINSTEIN and Paimre, 1969; Bondani and Karler, 1970; Thorpe and Seeman, 1971). Since procaine inhibited the rapid cooling contracture in isotonic K-Krebs solution having $\mathrm{pH}$ of 7.2-7.4 in which the charged form of procaine is dominant, Ca mobilization from its sequestered sites is considered to be inhibited by procaine (Figs. 11 and 12).

According to BrADING et al. (1969), K conductance is controlled by Ca especially at the inner layer of the cell membrane, and decrease in $\mathrm{Ca}$ at this site by cooling is postulated in the guinea pig taenia coli. Tomita and Watanabe (1973) also suggest that $\mathrm{K}$ permeability is controlled by the amount of bound $\mathrm{Ca}$ at the inner surface of the membrane and that pacemaker potential is influenced by this $\mathrm{Ca}$ in the taenia coli. Since procaine is considered to reduce $\mathrm{K}$ conductance and inhibit Ca mobilization from its sequestered sites in the guinea pig urinary bladder, pro- 
caine may act on $\mathrm{Ca}$ that is located at the inner surface of the cell membrane. However, it has not been clarified whether the $\mathrm{Ca}$ which controls $\mathrm{K}$ conductance is the same as that $\mathrm{Ca}$ which is mobilized by rapid cooling.

Recent investigations of procaine effects on the guinea pig urinary bladder would suggest that procaine at low concentrations enhances spontaneous contractions by increasing $\mathrm{Ca}$ spike activity which is initiated by the reduction of $\mathrm{K}$ conductance in normal Krebs solution, and that procaine has an inhibitory effect on contractions produced by $\mathrm{Ca}$ permeation through the cell membrane and $\mathrm{Ca}$ mobilization from sequestered sites when spike activities are abolished in high $\mathrm{K}-\mathrm{Krebs}$ solution. Importance of $\mathrm{Ca}$ current in $\mathrm{E}-\mathrm{C}$ coupling of the guinea pig urinary bladder should be emphasized.

I wish to thank Prof. A. Simpson, Showa University for his assistance in preparation of this manuscript.

\section{REFERENCES}

Branchi, C. P. and Bolton, T. C. (1967) Action of local anesthetics on coupling systems in muscle. J. Pharmacol. Exp. Ther., 157: 388-405.

BONDANI, A. and KARLER, R. (1970) Interaction of calcium and local anesthetics with skeletal muscle microsomes. J. Cell. Physiol., 75: 199-212.

Bülbring, E. and KurIYAMA, H. (1973) The action of catecholamines on guinea-pig taenia coli. Phil. Trans. R. Soc. Lond. B., 265: 115-121.

Brading, A., Bülbring, E., and Tomita, T. (1969) The effect of temperature on the membrane conductance of the smooth muscle of the guinea-pig taenia coli. J. Physiol., 200: 621-635.

CASTEELs, R. (1970) The relation between the membrane potential and the ion distribution in smooth muscle cells. In: Smooth Muscle, ed. by Bülbring, E., Brading, A. F., Jones, A. W., and TomitA, T. Edward Arnold, Ltd., London, pp. 70-99.

CASTEEls, R. and Kuriyama, H. (1966) Membrane potential and ion content in the smooth muscle of the guinea-pig's taenia coli at different external potassium concentrations. $J$. Physiol., 184: 120-130.

Creed, K. E. (1971) Membrane properties of the smooth muscle membrane of the guinea-pig urinary bladder. Pflügers Arch., 326: 115-126.

Edman, K. A. P. and Schild, H. O. (1962) The need for calcium in the contractile responses induced by acetylcholine and potassium in the rat uterus. J. Physiol., 161: 424-441.

Evans, D. H. L., Schild, H. O., and TheslefF, S. (1958) Effects of drugs on depolarized plain muscle. J. Physiol., 143: 474-485.

FEINSTEIN, M. B. (1966) Inhibition of contraction and clacium exchangeability in rat uterus by local anesthetics. J. Pharmacol. Exp. Ther., 152: 516-524.

Feinstein, M. B. and PAimre, M. (1969) Pharmacological action of local anesthetics on excitation-contraction coupling in striated and smooth muscle. Fed. Proc., 28: 1643-1648.

IMAI, S. and TAKEDA, K. (1967) Actions of calcium and certain multivalent cations on potassium contracture of guinea-pig's taenia coli. J. Physiol., 190: 155-169.

KuriharA, S. (1973) The effect of procaine on the urinary bladder smooth muscle of bullfrogs. Jap. J. Physiol., 23: 309-324.

Kuritara, S. (1975) The effect of procaine on the mechanical and electrical activities of the smooth muscle cells of the guinea pig urinary bladder. Jap. J. Physiol., 25: 775-788.

Kurihara, S. and Creed, K. E. (1972) Changes in the membrane potential of the smooth 
muscle cells of the guinea pig urinary bladder in the various environments. Jap. J. Physiol., 22: $667-683$.

Kurihara, S., KuriYama, H., and Magaribuchi, T. (1974) Effects of rapid cooling on the electrical properties of the smooth muscle of the guinea-pig urinary bladder. J. Physiol., 238: 413-426.

Kurihara, S. and SAKaI, T. (1976) Relationship between effects of procaine and Ca on spontaneous electrical and mechanical activities of the smooth muscle cells of the guinea pig urinary bladder. Jap. J. Physiol., 26: 487-501.

MAGARIBUCHI, T., Ito, Y., and KURIYAMA, H. (1973) Effects of rapid cooling on the mechanical and electrical activities of smooth muscles of guinea pig stomach and taenia coli. J. Gen. Physiol., 61: 323-341.

SAKAI, T. (1963) Action of the local anesthetics on the mechanical response of the caffeinized muscle by rapid cooling. Jikeikai Med. J., 10: 113-120.

SaKaI, T., Geffner, E.S., and SAndow, A. (1971) Caffeine contracture in muscle with disrupted transverse tubules. Am. J. Physiol., 220: 712-717.

SAKAI, T. and IIzUKA, T. (1972) The effect of caffeine and rapid cooling on smooth muscle. Jap. J. Physiol., 22: 135-145.

Thorpe, W. R. and SeEman, P. (1971) The site of action of caffeine and procaine in skeletal muscle. J. Pharmacol. Exp. Ther., 179: 324-330.

Tomita, T. and WATANABE, H. (1973) Factors controlling myogenic activity in smooth muscle. Phil. Trans. R. Soc. Lond. B., 265: 73-85.

Urakawa, N. and Holland, W. C. (1964) $\mathrm{Ca}^{45}$ uptake and tissue calcium in K-induced phasic and tonic contraction in taenia coli. Am. J. Physiol., 207: 873-876.

Weber, A. and Herz, R. (1968) The relationship between caffeine contracture of intact muscle and the effect of caffeine on reticulum. J. Gen. Physiol., 52: 750-759. 